\title{
Effect of ration composition fed to cows on the mobile bag digestibility
}

\section{S. Michalak ${ }^{1}$ M.R. Weisbjerg ${ }^{2}$ and T. Hvelplund ${ }^{2}$}

\author{
${ }^{1}$ August Cieszkowski Agricultural University, \\ Department of Animal Nutrition and Feed Management \\ Wotyńska 33, 60-637 Poznań, Poland \\ ${ }^{2}$ Danish Institute of Animal Science, \\ Department of Animal Nutrition and Physiology, Research Centre Foulum \\ 8830 Tjele, Denmark
}

(Received 23 April 2002; revised version 26 September 2002; accepted 20 December 2002)

\begin{abstract}
Four multiparous Danish Holstein Friesian cows fitted with rumen, duodenal and ileal cannulas were used in a $4 \times 4$ Latin square design. Treatments were arranged in a $2 \times 2$ factorial design to study the effect of different concentrate supplements on the intestinal digestibility of dry matter and nitrogen of artificially dried hay and rapeseed cake, estimated by the mobile bag method. Both original feeds and undegraded residues were examined. The cows were fed artificially dried hay ad libitum and one of four concentrate diets. The four concentrate diets represented two levels and two types of concentrate, where types were either dried sugar beet pulp or barley. High and low levels of concentrate were 6 and $1.5 \mathrm{~kg} /$ day, respectively. The type of the concentrates had no effect $(\mathrm{P}>0.05)$ on the total daily dry matter intake. Mobile bag $\mathrm{N}$ digestibility was generally not influenced by the ration fed to the cows. However, for undegraded residues of rapeseed cake a numerically small, but statistically significant higher mobile bag digestibility was found for dried sugar beet pulp compared to barley. For mobile bag dry matter digestibility the effects of ration were significant for both original and undegraded rapeseed cake whereas no effect was found for hay.
\end{abstract}

KEY WORDS: cows, ration composition, intestinal digestibility, mobile bag, dry matter, nitrogen

\section{INTRODUCTION}

The intestinal digestibility of rumen-undegraded protein is an important factor in the new protein evaluation systems for ruminants. The mobile bag method is a relatively easy and cheap technique compared to in vivo experiments for estimating 
post-gastric digestion (Hvelplund, 1985; De Boer et al., 1987; Hvelplund et al., 1992). The mobile bag method has been used to study intestinal digestibility of protein and amino acids in different concentrates (Weisbjerg et al., 1996) and roughages (Skórko-Sajko et al., 1994; Skiba et al., 1996). Studies of the mobile bag procedure done so far mainly refer to the bag-cloth characteristics, pepsin-hydrochloric acid pre-treatment of the sample and place of recovery (Voigt et al., 1985; Varvikko and Vanhatalo, 1990; Jarosz et al., 1994; Vanhatalo and Varvikko, 1995). It is suggested that the ration does not influence the intestinal digestibility, estimated with the mobile bag technique. This is based on the general low variation between results obtained from cows fed different diets. However, to our knowledge only one controlled experiment has examined the effect of ration on mobile bag digestibility, and here it was shown that ration composition had no effect, however increased feeding level reduced mobile bag digestibility (Vanhatalo and Ketoja, 1995).

The aim of the present experiment was to determine the effect of ration composition on the digestibility values of dry matter and nitrogen obtained using the mobile bag method. Artificially dried hay and rapeseed cake were used as experimental feeds.

\section{MATERIAL AND METHODS}

\section{Animals and experimental design}

Four multiparous Danish Holstein Friesian cows fitted with ruminal, duodenal and ileal cannulas were used in a $4 \times 4$ Latin square design with a $2 \times 2$ factorial arrangement of treatments involving two concentrate types (barley and dried sugar beet pulp) and two concentrate levels (high and low). Period length was 1 week. Mean liveweight of the animals was $748 \pm 56 \mathrm{~kg}$ at the beginning of period 1 and $743 \pm 52 \mathrm{~kg}$ at the end of period 4 (mean $\pm \mathrm{SE}$ ). Average milk yield was $16 \pm 3$ $\mathrm{kg}$ (mean $\pm \mathrm{SE}$ ). The cows were housed in a tie stall with free access to water and bedded on rubber mats.

\section{Feeding and rations}

The cows were fed two times a day (11.00 and 17.30) with a diet based on artificially dried hay offered ad libitum together with a restricted amount of one of two concentrate types fed either at a low $(1.5 \mathrm{~kg} / \mathrm{d})$ or a high $(6.0 \mathrm{~kg} / \mathrm{d})$ level of intake (Table 1). Replacing dried sugar beet pulp with barley reduced the content of crude fibre and increased the content of starch in the concentrates used. Hay and concentrates were fed in separate mangers. Amounts of feed offered and refused were recorded daily and dry matter content in feeds and residues were measured on 
samples from the last two days in each period. Eventually residues of concentrate were fed to the rumen through the fistulae. Representative samples of each feed were taken in each period and pooled over periods for chemical analyses.

TABLE 1

Composition of rations and chemical composition of feeds

\begin{tabular}{|c|c|c|c|c|c|c|c|c|}
\hline & \multicolumn{4}{|c|}{$\begin{array}{l}\text { Composition of ration } \\
\mathrm{kg} \mathrm{d}^{-1}\end{array}$} & \multicolumn{4}{|c|}{$\begin{array}{l}\text { Chemical composition of ingredients } \\
\mathrm{g} \mathrm{kg}^{-1} \mathrm{DM}\end{array}$} \\
\hline & \multicolumn{2}{|c|}{ barley } & \multicolumn{2}{|c|}{$\begin{array}{l}\text { dried sugar } \\
\text { beet pulp }\end{array}$} & \multirow{2}{*}{$\begin{array}{l}\text { crude } \\
\text { protein }\end{array}$} & \multirow{2}{*}{$\begin{array}{c}\text { crude } \\
\text { fat }\end{array}$} & \multirow{2}{*}{$\begin{array}{l}\text { crude } \\
\text { fibre }\end{array}$} & \multirow[t]{2}{*}{ ash } \\
\hline & high & low & high & low & & & & \\
\hline Barley & 5.0 & 1.0 & & & 108.1 & 32 & 52 & 22 \\
\hline Dried sugar beet pulp & & & 5.0 & 1.0 & 85.6 & 7 & 201 & 72 \\
\hline Soyabean meal & 1.0 & 0.5 & 1.0 & 0.5 & 491.2 & 30 & 72 & 91 \\
\hline Artificial dried hay & ad lib & tum & & & 121.3 & 23 & 288 & 88 \\
\hline
\end{tabular}

\section{Feeds and mobile bag procedure}

The feeds used for mobile bag incubations were artificially dried hay and rapeseed cake. Both original feed and undegraded residues after $16 \mathrm{~h}$ rumen incubation were used (Table 2). To produce rumen undegraded residues, feed were incubated in two cows fed a standard ration (1/3 concentrate, $2 / 3$ hay) using large nylon bags (Dakowski et al., 1996). The small intestinal digestibility of dry matter and nitrogen of original and rumen undegraded residues were measured

TABLE 2

Chemical composition of the original feeds and undegraded residues after $16 \mathrm{~h}$ incubation in the rumen used for mobile bags

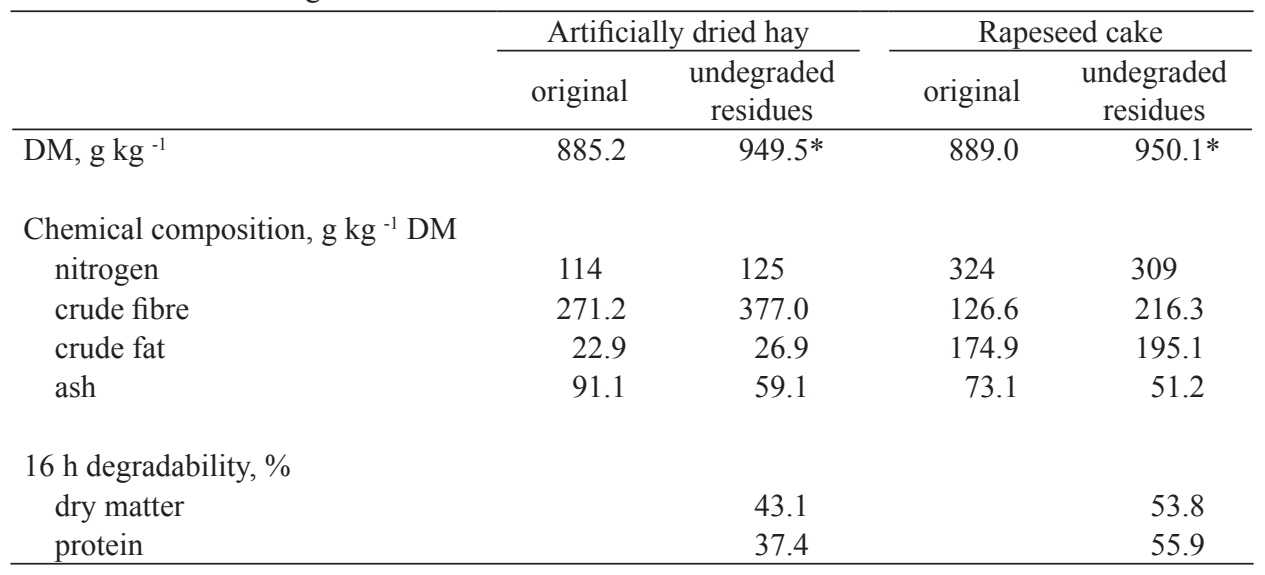

* freeze dried material 
according to the procedure for mobile bags described by Hvelplund and Weisbjerg (2000). However, the $16 \mathrm{~h}$ preincubation of mobile bags in the rumen (which is used in the standard procedure) was omitted, as in this study both original feeds and undegraded feeds were used for mobile bag incubations. For each experimental feed, 12 identical sets of bags ( 3 per cow) were first soaked for one h in $\mathrm{HCl}(\mathrm{pH}$ 2.4) and then incubated for two $\mathrm{h}$ at $40^{\circ} \mathrm{C}$ in pepsin- $\mathrm{HCl}(0.2 \mathrm{~g}$ pepsin $1: 10000$ in 2 $1 \mathrm{HCl} \mathrm{pH} \mathrm{2.4).} \mathrm{Then} \mathrm{bags} \mathrm{were} \mathrm{introduced} \mathrm{into} \mathrm{the} \mathrm{duodenum} \mathrm{(12} \mathrm{bags} \mathrm{per} \mathrm{cow} \mathrm{per}$ period) between 11.00 and 12.00 o'clock on Wednesdays. 192 bags were introduced to the rumen during the entire experiment ( 4 cows $\mathrm{x} 4$ periods $\mathrm{x} 4$ incubated feeds $\mathrm{x}$ 3 repetitions $=192$ ). From these, 183 mobile bags were recovered in the faeces.

\section{Estimation of standard protein values}

Dry matter and nitrogen degradability of artificially dried hay and rapeseed cake were determined using the nylon bag method described by Madsen and Hvelplund (1994). Bag residue from the hay was treated with a stomacher (Michalet-Doreau and Ould-Bah, 1992) to remove adhering microbes. The intestinal digestibility of dry matter and nitrogen of the tested feeds were measured according to the standard procedure for mobile bags (Hvelplund and Weisbjerg, 2000).

\section{Chemical analyses, calculations and statistical analyses}

Experimental feeds and feeds used in the ration were analysed for dry matter, ash, nitrogen, crude fat and crude fibre according to conventional methods (AOAC, 1990). Effective degradability (ED) was calculated according to Ørskov and McDonald (1979) using PROC NLIN (SAS, 1996). ED was corrected for loss of small particles according to Weisbjerg et al. (1990). All data were statistically analysed using the GLM procedure of SAS (1996), with the model:

$$
\mathrm{Y}_{\mathrm{ijk} k}=\mu+\mathrm{A}_{\mathrm{i}}+\mathrm{P}_{\mathrm{j}}+\mathrm{T}_{\mathrm{k}}+\mathrm{L}_{1}+(\mathrm{T} \times \mathrm{L})_{\mathrm{kl}}+\varepsilon_{\mathrm{ijkl}}
$$

where: A, P, T, L and T $x \mathrm{~L}$ are effect of animal ( $\mathrm{i}=1$ to 4$)$, period $(\mathrm{j}=1$ to 4$)$, concentrate type $(\mathrm{k}=$ barley and dried sugar beet pulp), concentrate level $(1=$ high and low) and interaction between concentrate type and level. Results are reported as least square means for each treatment. The variation is given as standard error of the least square means (SEM).

\section{RESULTS}

The chemical composition of feeds is shown in Table 1, and all values are within the expected range for these feeds and meet the criteria for the planned feeding of the cows with a concentrate with high or low fibre content. 
Chemical composition of original feeds and rumen undegraded residues after $16 \mathrm{~h}$ incubation in the rumen is shown in Table 2 together with the degradabilities obtained during the $16 \mathrm{~h}$ incubation. DM and protein degradation during $16 \mathrm{~h}$ incubation were 43.1 and $37.4 \%$ for artificially dried hay and 53.8 and $55.9 \%$ for rapeseed cake, respectively. The content of nitrogen, crude fibre and crude fat increased during $16 \mathrm{~h}$ incubation in the rumen, except for nitrogen in the rapeseed cake. In contrast, the ash content decreased for both feeds during $16 \mathrm{~h}$ incubation in the rumen (Table 2). The effective protein degradability and intestinal digestibility estimated with the nylon bag techniques according to the standard procedures are given in Table 3, and show substantial differences in the obtained values on both rumen degradability and intestinal digestibility of the undegraded feeds.

TABLE 3

Degradability and digestibility $( \pm$ SEM) of nitrogen estimated using standard methods with cows, $\%$

\begin{tabular}{lcc}
\hline & Artificially dried hay & Rapeseed cake \\
\hline EPD $^{1}$ & $48.3 \pm 2.4$ & $66.9 \pm 2.0$ \\
Intestinal digestibility $^{2}$ & $64.7 \pm 1.4$ & $90.8 \pm 0.3$ \\
Intestinal digestibility of RUP $^{3}$ & 31.6 & 72.1 \\
\hline
\end{tabular}

${ }^{1}$ effective protein degradability calculated for $5 \%$ passage rate and corrected for particle loss

${ }^{2}$ measured in mobile bags including $16 \mathrm{~h}$ pre-incubation in the rumen

${ }^{3}$ rumen undegraded protein, digestibility calculated as shown by Hvelplund et al. (1992)

TABLE 4

The effect of diet composition on daily dry matter intake of the experimental diets and digestibility of dry matter and nitrogen of the original feeds $(\mathrm{O})$ and undegraded residues $(\mathrm{U})$ after $16 \mathrm{~h}$ incubation in the rumen

\begin{tabular}{|c|c|c|c|c|c|c|c|c|}
\hline & \multicolumn{2}{|c|}{ Barley } & \multicolumn{2}{|c|}{$\begin{array}{c}\text { Dried sugar } \\
\text { beet pulp }\end{array}$} & \multirow{2}{*}{ SEM } & \multicolumn{3}{|c|}{$P$ values } \\
\hline & high & low & high & low & & type & level & $\begin{array}{l}\text { type } x \\
\text { level }\end{array}$ \\
\hline Dry matter intake, kg & 17.2 & 15.0 & 16.6 & 15.0 & 0.6 & 0.59 & 0.02 & 0.66 \\
\hline \multicolumn{9}{|l|}{ Digestibility DM, \% } \\
\hline hay (O) & 38.5 & 37.5 & 37.6 & 38.7 & 0.7 & 0.82 & 1.00 & 0.18 \\
\hline hay (U) & 16.1 & 17.4 & 17.1 & 16.5 & 0.3 & 0.94 & 0.37 & 0.03 \\
\hline rapeseed $(\mathrm{O})$ & 69.1 & 70.4 & 76.5 & 71.2 & 1.1 & 0.01 & 0.13 & 0.03 \\
\hline rapeseed (U) & 48.8 & 50.1 & 52.7 & 53.9 & 0.9 & 0.01 & 0.21 & 0.97 \\
\hline \multicolumn{9}{|l|}{ Digestibility N, \% } \\
\hline hay $(\mathrm{O})$ & 63.5 & 64.2 & 62.6 & 64.6 & 0.7 & 0.73 & 0.09 & 0.37 \\
\hline hay (U) & 64.9 & 66.8 & 66.4 & 67.3 & 0.8 & 0.25 & 0.11 & 0.57 \\
\hline rapeseed $(\mathrm{O})$ & 89.1 & 90.0 & 90.9 & 90.0 & 0.5 & 0.11 & 0.92 & 0.10 \\
\hline rapeseed (U) & $79.3^{1}$ & 79.7 & 80.1 & 80.7 & 0.3 & 0.02 & 0.16 & 0.78 \\
\hline
\end{tabular}

${ }^{1}$ SEM is 0.36 , because samples for period 2 were lost 


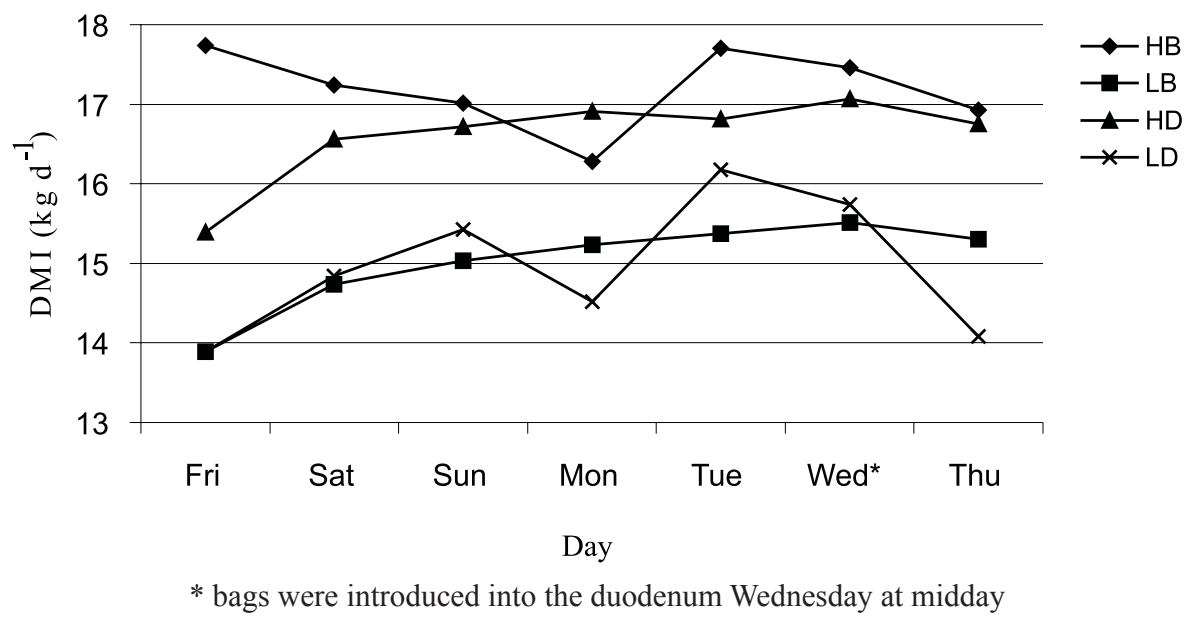

Figure 1 . Weekly variation in daily dry matter intake of the four experimental diets $\left(\mathrm{kg} \mathrm{d}^{-1}\right)$. HB - high barley, HD - high dried sugar beet pulp, LB - low barley, LD - low dried sugar beet pulp

The average daily intake of dry matter on the four different treatments is shown in Table 4. The type of the concentrates had no effect $(\mathrm{P}>0.05)$ on the intake of the diets (Table 4). However, high concentrate level significantly $(\mathrm{P}<0.05)$ increased intake of dry matter. The daily intake of each diet is also illustrated in Figure 1, showing some daily variation, but no major effect of introducing nylon bags to the intestine. Mobile bags were introduced on Wednesday around midday, and an eventual negative effect should then have been on intake on Wednesday or Thursday. No correlation was observed between individual dry matter intake and intestinal digestibility (data is not presented).

The type of ration had no effect on mobile bag intestinal digestibility of dry matter in artificially dried hay (Table 4), although there was a significant interaction for undegraded residues of hay. However, for rapeseed cake a higher intestinal digestibility of dry matter was observed for the rations containing dried sugar beet pulp (average $73.9 \%$ for original feeds and 53.3\% for undegraded residues) compared to rations containing barley (average $69.8 \%$ for original feeds and $49.4 \%$ for the undegraded residue). These differences were highly significant $(\mathrm{P}<0.01)$. Level of concentrates in the ration had no effect $(\mathrm{P}>0.05)$ on intestinal digestibility of dry matter, but significant interactions were found for original rapeseed cake.

Mobile bag intestinal digestibility of nitrogen was not affected by the type of ration, except for undegraded residues of rapeseed cake, where type of concentrate had a statistically significant effect (Table 4). However, numerically the effect was very small, and the biggest difference was 1.4 percent unit between high barley and low dried sugar beet pulp. The average intestinal digestibility of the nitrogen was $63.7 \%$ for hay, $66.3 \%$ for rumen undegraded residues of hay, $89.0 \%$ for rapeseed cake and $80.0 \%$ for rumen undegraded residues of rapeseed cake. 


\section{DISCUSSION}

The results from Tables 3 and 4 shows that there are only minor differences between the mobile bag intestinal digestibilities of nitrogen found with the standard method including $16 \mathrm{~h}$ pre-incubation in the rumen (Table 3 ) and the values obtained for original feed without pre-incubation as shown in Table 4. For rapeseed cake the standard method gave $90.8 \%$ (Table 3), whereas results ranged from 89.0 to $90.9 \%$ for the original rapeseed cake (Table 4 ). For hay the standard method gave $64.7 \%$ (Table 3 ), whereas results ranged from 62.6 to $64.6 \%$ for original hay (Table 4). These data are in agreement with results obtained for protein rich concentrates by different authors (Hvelplund et al., 1992; Volden and Harstad, 1995; Mupeta et al., 1997), who also found numerically small effects of rumen pre-incubation on total availability. However, a slight influence of pre-incubation in the rumen on the intestinal digestibility of nitrogen was observed in this experiment. This is probably due to some cell wall bound $\mathrm{N}$, which can be degraded in the rumen, where cellulolytic and proteolytic microbial enzymes are present (Hvelplund and Weisbjerg, 2000). The effect of rumen pre-incubation can be expected especially for forages, and is very large for some tropical roughages (Mgheni et al., 1994). Rumen pre-incubation is also essential to obtain total availability for some starchcontaining feeds (Weisbjerg et al., 1996).

Mobile bag $\mathrm{N}$ digestibility was approximately 10 percent units lower for undegraded residues of rapeseed cake compared to original rapeseed cake. As $\mathrm{N}$ degradation in long nylon bags was $55.9 \%$, a digestibility of $79.1 \%=[(90.8-55.9)$ $\mathrm{x} 100 /(100-55.9)]$ was expected, which is very close to the measured values, which were between 79.3 and $80.7 \%$.

Astonishingly, mobile bag digestibility of $\mathrm{N}$ was slightly higher for undegraded residues of hay than for original hay. This was not expected, as digestibility of undegraded residues normally decreases with increased rumen degradation and a digestibility of approx. $44 \%=[(64.7-37.4) \times 100 /(100-37.4)]$ would have been expected instead of the measured values varying from 64.9 to $67.3 \%$ (Hvelplund et al., 1992). The higher values than expected for the undegraded protein in the artificially dried hay may be an effect of Maillard products as the low intestinal digestibility of the original protein estimated with the standard procedure (Table 3 ) is approximately 20 percent units lower than expected. Why the samples incubated in the long nylon bags for $16 \mathrm{~h}$ and having a degradability in the rumen of $37.4 \%$ showed values for the intestinal digestibility which were 20 percent units higher than expected remains unexplained.

Both for rapeseed cake and hay the values given in Table 4 for mobile bag digestibilities of undegraded residues were higher than the calculated values for intestinal digestibility of rumen undegraded protein in Table 3, based on values from standard methods. The main reason for the discrepancy is that the 'standard' 
effective degradability given in Table 3 is higher for both feeds compared to the degradability obtained after $16 \mathrm{~h}$ incubation (Table 2 ) producing the undegraded residues used for obtaining the values in Table 4.

Mobile bag $\mathrm{N}$ digestibility was generally not influenced by the diet fed to the cows. Only for undegraded residues of rapeseed cake a statistically significant but numerically small effect was found for type of concentrate, where dried sugar beet pulp gave slightly higher values than barley. For mobile bag dry matter digestibility similar effects of type of concentrate was found for both original and undegraded residues of rapeseed cake, and for DM the numerical size of the effect was larger. The reason for this, and some interactions between type of concentrate and concentrate level is not known, but could possibly be an effect on either enzyme secretion, enzyme activity in the intestinal chyme, an effect on mobile bag retention time in the small intestine and in the hind gut, or microbial activity in the hind gut.

\section{CONCLUSIONS}

Nitrogen digestibility determined with the mobile bag was in general not influenced by the ration (concentrate type and level) fed to the cows. Only for undegraded residues of rapeseed cake a statistically significant but numerically small effect was found for the type of concentrate. The effects of ration were larger for mobile bag dry matter digestibility. In conclusion, diet composition seems to have minor effect on mobile bag $\mathrm{N}$ digestibility. However, earlier experiments (Vanhatalo and Ketoja, 1995) found an effect of feeding level.

\section{ACKNOWLEDGEMENTS}

The authors acknowledge Ejner Serup, Edith Olsen and Hanne Pedersen for their valuable technical assistance.

\section{REFERENCES}

AOAC, 1990. Official Methods of Analysis, Association of Official Analytical Chemists. $15^{\text {th }}$ Edition. Arlington, VA

Dakowski P., Weisbjerg M.R., Hvelplund T., 1996. The effect of temperature during processing of rape seed meal on amino acid degradation in the rumen and digestion in the intestine. Anim. Feed Sci. Tech. 58, 213-226

DeBoer G., Murphy J.J., Kennelly J.J., 1987. Mobile nylon bag for estimating intestinal availability of rumen undegradable protein. J. Dairy Sci. 70, 977-982 
Hvelplund T., 1985. Digestibility of rumen microbial protein and undegraded dietary protein estimated in the small intestine of sheep or by in sacco procedure. Acta Agr. Scand., Suppl. 25, 132-144

Hvelplund T., Weisbjerg M.R., 2000. In situ techniques for estimation of protein degradabililty and postrumen availability. In: D.I. Givens, E. Owen, R.F.E. Axford, H.M. Omed (Editiors). Forage Evaluation in Ruminant Nutrition. CABI Publishing, Wallingford, pp. 233-258

Hvelplund T., Weisbjerg M.R., Andersen L.S., 1992. Estimation of the true digestibility of rumen undegraded dietary protein in the small intestine of ruminants by the mobile bag technique. Acta Agr. Scand., Sect. A, Anim. Sci. 42, 34-39

Jarosz L., Hvelplund T., Weisbjerg M.R., Jensen B.B., 1994. True digestibility of protein in the small intestine and the hind gut of cows measured with the mobile bag technique using ${ }^{15} \mathrm{~N}$ labelled roughage. Acta Agr. Scand., Sect. A, Anim. Sci. 44, 146-151

Madsen J., Hvelplund T., 1994. Prediction of in situ protein degradability in the rumen. Results of an European ringtest. Livest. Prod. Sci. 39, 201-212

Michalet-Doreau B., Ould-Bah M.Y., 1992. In vitro and in sacco methods for the estimation of dietary nitrogen degradability in the rumen: a review. Anim. Feed Sci. Tech. 40, 57-86

Mgheni D.M., Hvelplund T., Weisbjerg M.R., 1994. Intestinal digestibility of rumen undegraded dietary protein from tropical roughages estimated by the mobile bag technique. Acta Agr. Scand., Sect. A, Anim. Sci. 44, 230-235

Mupeta B., Weisbjerg M.R., Hvelplund T., Madsen J., 1997. Digestibility of amino acids in protein rich tropical feeds for ruminants estimated with the mobile bag technique. Anim. Feed Sci. Tech. 69, 271-280

Ørskov E.R., McDonald I., 1979. The estimation of protein degradability in the rumen from incubation measurements weighted according to rate of passage. J. Agr. Sci. 92, 499-503

SAS $^{\circledR}, 1996$. SAS User's Guide: Statistics, Version 6.12. SAS Inst., Inc., Cary, NC

Skiba B., Weisbjerg M.R., Hvelplund T., 1996. Rumen and total intestinal tract digestibility of protein and amino acids from different roughages, determined in situ. J. Anim. Feed Sci. 5, 347-363

Skórko-Sajko H., Hvelplund T., Weisbjerg M.R., 1994. Rumen degradation and intestinal digestibility of amino acid in different roughages estimated by nylon bag techniques. J. Anim. Feed Sci. 3, 1-10

Vanhatalo A., Ketoja E., 1995. The role of the large intestine in post-ruminal digestion of feeds as measured by the mobile-bag method in cattle. Brit. J. Nutr. 73, 491-505

Vanhatalo A., Varvikko T., 1995. Effect of rumen degradation on intestinal digestion of nitrogen of ${ }^{15} \mathrm{~N}$-labelled rapeseed meal and straw measured by the mobile-bag method in cows. J. Agr. Sci. $125,253-261$

Varvikko T., Vanhatalo A., 1990. The effect of differing types of cloth and of contamination by nonfeed nitrogen on intestinal digestion estimates using porous syntethic-fibre bags in a cow. Brit. J. Nutr. 63, 221-229

Voigt J., Piatkowski B., Engelmann H., Rudolph E., 1985. Measurement of the postruminal digestibility of crude protein by the bag technique in cows. Arch. Tierernähr. 35, 555-562

Volden H., Harstad O.M., 1995. Effect of rumen incubation on the true indigestibility of feed protein in the digestive tract determined by nylon bag techniques. Acta Agr. Scand., Sect A, Anim. Sci. 45, 106-115

Weisbjerg M.R., Bhargava P.K., Hvelplund T., Madsen J., 1990. Use of degradation curves in feed evaluation. Report 679, National Institute of Animal Science, Foulum (Denmark), pp. 33

Weisbjerg M.R., Hvelplund T., Hellberg S., Olsson S., Sanne S., 1996. Effective rumen degradability and intestinal digestibility of individual amino acids in different concentrates determined in situ. Anim. Feed Sci. Tech. 62, 179-188 


\section{STRESZCZENIE}

\section{Wpływ składu dawki na strawność oznaczaną metodą woreczków mobilnych u krów}

Doświadczenie, w układzie kwadratu łacińskiego, przeprowadzono na 4 krowach wieloródkach, duńskich holsztyno-fryzach z przetokami żwacza, dwunastnicy i jelita biodrowego. Badano $(2 \times 2$ układ czynnikowy) wpływ różnego dodatku paszy treściwej do dawki na strawność jelitową suchej masy i azotu mechanicznie wysuszonego siana i makuchu rzepakowego, stosując metodę woreczków mobilnych. Krowy otrzymywały do woli siano i jedną z czterech dawek, zwierających dwa poziomy i dwa rodzaje paszy treściwej (suszone wysłodki buraczane lub jęczmień). Dawka paszy treściwej wynosiła 6 lub 1,5 kg, odpowiednio wysoka i niska.

Rodzaj paszy treściwej nie miał wpływu $(\mathrm{P}>0,05)$ na całkowite dzienne pobranie suchej masy, a rodzaj skarmianej dawki nie miał wpływu na jelitową strawność N. Jednakże, w przypadku nie rozłożonych pozostałości makuchu rzepakowego, choć ilościowo było ich mało, stwierdzono statystycznie istotnie lepszą strawność przy dodatku wysłodków buraczanych niż jęczmienia. Wykazano, że rodzaj dawki miał istotny wpływ na strawność suchej masy, tak całej jak i części nierozłożonej w żwaczu, makuchu rzepakowego, natomiast nie miał wpływu na strawność siana. 